\title{
Stronger together: understanding and protecting karst resources
}

\author{
Lee Anne Bledsoe ${ }^{1}\left[\right.$ [D $\cdot$ Ben Tobin $^{2} \cdot$ Chris Groves $^{1}$ \\ Accepted: 3 October 2021 / Published online: 9 December 2021 \\ (C) The Author(s), under exclusive licence to Springer-Verlag GmbH Germany, part of Springer Nature 2021
}

\begin{abstract}
The United Nations Educational, Scientific, and Cultural Organization (UNESCO) has recognized more than 350 karst areas of global importance through various designations (Biosphere Reserve, World Heritage Sites, Ramsar Sites, and Global Geoparks) with at least one UNESCO protected area with karst in 86 countries (Gunn 2020). In August 2020, Western Kentucky University, the George Wright Society, and the UNESCO Mammoth Cave Biosphere Region hosted Conservation of Fragile Karst Resources: A Virtual Workshop on Sustainability and Community in support of UNESCO science programs. The purpose of this meeting was to enhance communication and the sharing of ideas and resources between major conservation and science programs that protect, study, or manage cave and karst resources, with particular interest to those of international significance. This special issue is published in celebration and support of the UIS International Year of Caves and Karst and as a call-to-action to better explore, understand, and protect the value of cave and karst areas to humanity in both our everyday lives as well as our natural and cultural heritage.
\end{abstract}

Keywords UNESCO $\cdot$ International Year of Caves and Karst · Hydrogeology $\cdot$ Geoheritage $\cdot$ Protected areas $\cdot$ International cooperation

Karst landscapes, areas of the earth's surface with solutionally driven erosion that results in the formation of caves, sinkholes, and large springs, are found throughout the world. These landscapes and associated aquifer systems are estimated to constitute about $15 \%$ of the earth's ice-free land surface and supply water resources for $13-25 \%$ of the world's population (Ford and Williams 2013; Stevanović 2019). The United Nations Educational, Scientific, and Cultural Organization (UNESCO) has recognized more than 350 karst areas of global importance through various designations (Biosphere Reserve, World Heritage Sites, Ramsar Sites, and Global Geoparks) with at least one UNESCO protected area with karst in 86 countries. These statistics do not include protected areas with caves in other geologic settings, which also deserve special consideration (Gunn 2020). In August 2020, Western Kentucky University, the

Lee Anne Bledsoe

lee.bledsoe@wku.edu

1 Crawford Hydrology Laboratory, Department of Earth, Environmental, and Atmospheric Sciences, Western Kentucky University, Bowling Green, KY 42101, USA

2 Kentucky Geological Survey, University of Kentucky, Lexington, KY 40506, USA
George Wright Society, and the UNESCO Mammoth Cave Biosphere Region hosted Conservation of Fragile Karst Resources: A Virtual Workshop on Sustainability and Community in support of UNESCO science programs. The purpose of this meeting was to enhance communication and the sharing of ideas and resources between major conservation and science programs that protect, study, or manage cave and karst resources, with particular interest to those of international significance. Recognizing the unique challenges to understanding and protecting karst landscapes and the multifaceted nature of environmental conservation, the workshop focused on presenting holistic approaches spanning multiple disciplines.

The workshop was attended by a diverse group of more than 80 resource managers, scientists, educators, and community partners from across 18 countries, representing programs such as the UNESCO/International Union of Geological Sciences (IUGS) International Geoscience Program project IGCP\#661, the International Association of Hydrogeologists Karst Commission, the World Karst Aquifer Map (WOKAM) program, the IUCN Cave and Karst Working Group, the Union Internationale de Spéléologie (UIS) and other organizations and researchers working with or in UNESCO Biosphere Reserves, World Heritage Sites, and Global 
Geoparks. Oral presentations, virtual field trips, and interactive workshop sessions allowed participants to share successes and challenges in promoting sustainability and community involvement in karst conservation. As we continue to navigate the current global public health crisis resulting from the COVID-19 virus, climate change, and other issues of social and environmental justice, it is paramount that we implement best practices across cave and karst landscapes and focus on supporting sustainable, resilient communities. This special issue is a continuation of our call-to-action for international cooperation in conserving the delicate karst resources of our planet and the well-being of people who form an integral part of these ecosystems.

Through this collection of papers, the authors highlight the challenges of both living in and studying karst systems. Water flow is dominated by subsurface flow paths, so hydrologists cannot rely on topographic maps. Just to map out the basic flow paths methods that have been developed specifically for karst aquifers that must be employed (e.g. Goldscheider and Drew 2007) including fluorescent dye tracing, mapping of underground rivers through direct exploration or geophysics, and high-resolution monitoring of integrative springs. These methods are now well established and used in karst terrains, often combined with traditional techniques. At the same time, some methods typically employed for investigating porous media aquifer systems are not readily applicable for the study of karst groundwater flow, as most of the flow is typically through discrete conduits. Wells-a mainstay for groundwater monitoring in porous media aquifers-often make ineffective groundwater monitoring points. Quinlan and Ewers (1986) wrote that the "probability of a randomly located monitoring well intercepting the trunk conduit which drains a groundwater basin, or the tributary conduit which drains a site, is similar to the probability of a dart thrown at a wall map of the United States hitting the Mississippi River or a specific tributary." The numerical modeling tools used to simulate the flow and contamination of porous media aquifers are also of limited use in informing remediation strategies in karst aquifers. As a result, many of the remedies developed in other landscapes prove to be ineffective in understanding and mitigating some of the major issues of living on karst landscapes. On top of struggling to contain issues such as water contamination or soil loss, the addition of sinkhole collapse concerns adds another major challenge to living on and studying karst. While the focus on groundwater is critical to understanding and protecting karst systems, integration with other research is necessary to fully understand the environmental and cultural significance of these special geoheritage areas.

\section{International communication in karst science}

These global challenges highlight that an international communication infrastructure to share information and experiences is critical. Fortunately, there are a number of groups that work to provide this function, several which are associated with UNESCO scientific programs. Three such global programs emerged in the early 1970s: the Man and the Biosphere Program, the Ramsar Convention, and the World Heritage Convention, all of which recognize both the natural and cultural world as intertwined and important to all people and enlist global cooperation in protecting them. The extent of cave and karst resources within these internationally designated sites has just begun to be evaluated as described in our introduction (Gunn 2020). UNESCO Global Geoparks, more recently formed in 2001 and included in Gunn's (2020) research, are but one pillar of the International Geoscience and Geoparks Program (IGGP). The second pillar is the International Geoscience Program (IGCP), which still retains its acronym IGCP from an earlier program name. Since 1990, six five-year, karstfocused projects have been implemented by UNESCO, the International Union of Geological Sciences (IUGS) and the Swedish International Development Cooperation Agency through the IGCP (Groves et al., 2012). Hundreds of karst scientists have participated in conferences throughout the world, including fieldwork in many of the world's iconic karst landscapes, and many valuable relationships have been created and nurtured through these collaborations. Since 2008, the International Research Center on Karst Under the Auspices of UNESCO (IRCK), housed at the Institute of Karst Geology in Guilin, China, implements annual karst hydrogeology training courses, and hundreds of students from throughout the world have benefitted. Beyond UNESCO, but with some overlap of membership in the IGCP Projects, there are also professional Karst Commissions of the International Association of Hydrogeologists (IAH) and the International Geographical Union (IGU). Although, as the world's largest organization focused on caves and karst, the UIS covers a broad range of interests, there is an emphasis in international communication and collaboration in hydrogeology within the UIS Commission on Karst Hydrogeology and Speleogenesis. It is through open communication between programs and across disciplines that we can establish healthy, sustainable relationships between people and cave and Karst environments while preserving our natural and cultural heritage.

During the Conservation of Fragile Karst Resources workshop, authors shared examples of collaborative management, assessments of protected area visitor use, sustainable geotourism, cultural heritage, citizen science, and 
environmental education programs and research, as well as a broad spectrum of hydrogeological studies from around the world. We offer a collection of papers in this special issue to highlight those topics and ask cave and karst scientists to explore ways to help your communities better understand and manage these exceptionally important landscapes.

Working toward the common goal of improved well-being through sustainable management of our natural resources requires rigorous scientific research as well as understanding the motivations and needs of local communities. To combine multiple disciplines and seek different perspectives is to be better prepared to address conservation challenges and find solutions that work best for people and the landscape. In our opening session, Stronger Together, A Global Conversation, experts from different karst disciplines around the globe discussed the importance of recognizing our earth as an interconnected system rather than discrete spheres or biomes; karst areas especially allow us to examine this intersection of geology, biodiversity, and culture (Kambesis et al. 2020). The papers presented herein are from multidisciplinary teams exploring that nexus as a new approach to better understand both the physical and cultural landscape as we work towards sustainable development goals (United Nations 2015).

The natural world is inextricably linked to our cultural heritage and modern livelihoods. As published herein, Kranjc illustrates this connection with the historical use and management of karst resources as tools for sustainable water use in preparation of a changing planet, while Stevanovic and others describe modern ways to better manage water resources in a protected karst area in the western Balkans. Karst groundwater is not only an important drinking source for more than $10 \%$ of the world's population (Stevanović 2019) but is also critical to ecological function (Butscher and Huggenberger 2009). Vulnerable to contamination, karst systems are also sensitive to changes in precipitation and temperature, therefore climate change has the potential to disrupt the quantity of freshwater available for both human use and ecosystem health (Pardo-Igúzquiza et al. 2019). As Arpin and Kambesis share in this issue, "a holistic approach to storing, accessing, and processing data is key to better understanding, management, and protection of vulnerable resources, environments, and ecosystems" (Kambesis et al. 2020). Cave and karst managers are often faced with competing priorities in determining sustainable use of natural resources. Presented during the Karst 2020 workshop, Telbiz and others assessed geological and biological values of Tara National Park, Serbia, paired with surveys of locals, tourists, park managers, and scientists to improve management of this "nature-tourism-community triangle." Perhaps we should expand that, allowing room for everyone at the table.
This special issue provides examples of how to engage, educate, and empower others to support and promote cave and karst conservation, and this is our principal challenge. Not to diminish the socio-economic, political, technological, and public health hurdles before us, but we must find ways to better communicate with each other, across borders, to local leaders and community partners, to our neighbors. By that token, this special issue is published in celebration and support of the UIS International Year of Caves and Karst 2021 (IYCK). The UIS calls us to help everyone explore, understand, and protect the value of cave and karst areas to humanity in both our everyday lives and our natural and cultural heritage. We hope this collection of papers inspires you to join us in the celebration and the international effort to conserve fragile karst resources.

\section{References}

Butscher C, Huggenberger P (2009) Modeling the temporal variability of karst groundwater vulnerability, with implications for climate change. Environm Sci Technol 43:1665-1669

Ford D, Williams PD (2013) Karst hydrogeology and geomorphology. John Wiley \& Sons

Goldscheider N, Drew D (2007) Methods in karst hydrogeology. Taylor and Francis, New York

Groves C, Zhang C, Yuan D (2012) IGCP 299, 379, 448, 513, and 598: Global efforts to understand the nature of karst systems: over two decades with the IGCP. In: Derbyshire E (ed), Tales Set in Stone - 40 Years of the International Geoscience Programme. Paris: UNESCO 80-87[BL2]

Gunn J (2020) Karst groundwater in UNESCO protected areas: a global overview. Hydrogeol J 2020:1-18

Kambesis P, Singer A, Bledsoe L (2020) Proceedings for conservation of fragile Karst resources: A virtual workshop on sustainability and community in support of UNESCO science programs. Available $(11 / 20 / 20)$ at https://digitalcommons.wku.edu/con_karst_ res_proc/

Pardo-Igúzquiza E, Collados-Lara AJ, Pulido-Velazquez D (2019) Potential future impact of climate change on recharge in the Sierra de las Nieves (southern Spain) high-relief karst aquifer using regional climate models and statistical corrections. Environm Earth Sci 78(20):598

Quinlan JF, Ewers RO (1986) Reliable monitoring in karst terranes: it can be done, but not by an EPA-approved method, Ground Water Monit Remediat

Stevanović Z (2019) Karst waters in potable water supply: a global scale overview. Environm Earth Sci 78(23):662. https://doi.org/ $10.1007 / \mathrm{s} 12665-019-8670-9$

United Nations (2015) Transforming our world: the 2030 agenda for sustainable development A/RES/70/1. Available (11/29/20) at https://sustainabledevelopment.un.org/post2015/transformingour world/publication

Publisher's Note Springer Nature remains neutral with regard to jurisdictional claims in published maps and institutional affiliations. 